\title{
Prenatally Diagnosed Primary Frontoethmoidal Encephalocele: A Case Report
}

Ebru Çelik Kavak, ${ }^{1}$ Salih Burçin Kavak, ${ }^{1}$ Ahmet Yalinkaya, ${ }^{2}$ Hakan Artaş, ${ }^{3}$ Numan Çim ${ }^{4}$

'Department of Obstetrics and Gynecology, Firat University Faculty of Medicine, Elazığ, Turkey

${ }^{2}$ Department of Obstetrics and Gynecology, Dicle University Faculty of Medicine, Diyarbakır, Turkey

${ }^{3}$ Department of Radiology, Firat University Faculty of Medicine, Elazığ, Turkey

${ }^{4}$ Department of Obstetrics and Gynecology, Yüzüncü Yıl University Faculty of Medicine, Van, Turkey

Submitted: 23.08 .2015 Accepted: 14.12.2015

Correspondence: Salih Burçin Kavak,

Fırat Üniversitesi Tıp Fakültesi, Kadın Hastalıkları ve Doğum Anabilim

Dalı, 23100 Elazığ, Turkey

E-mail: burcinkavak@yahoo.com

口ifing

Keywords: Frontoethmoidal encephalocele; prenatal period; ultrasonography.

\begin{abstract}
The present study aimed to report a case of primary frontoethmoidal encephalocele diagnosed at 24 weeks of gestation. Encephalocele is one of the most commonly observed neural tube defects; the other two are anencephaly and spina bifida. No associated abnormality was observed in the present case, which only had a mass lesion in the glabellar region of the face. Frontoethmoidal encephalocele was diagnosed after physical examination and radiologic evaluation of the case. Frontoethmoidal encephaloceles are rare cases and can be diagnosed in the antenatal period. All masses at the nasal region must be accepted as an encephalocele until proven otherwise.
\end{abstract}

\section{INTRODUCTION}

Encephalocele is one of the most commonly observed neural tube defects; the other two are anencephaly and spina bifida. Encephaloceles are divided into two types according to the cause: Primary encephaloceles are congenital and present at birth, and secondary encephaloceles occur later due to trauma or surgery. ${ }^{[1-3]}$ Primary encephaloceles are further divided into three types: frontoethmoidal, basal, and occipital, according to the position of bone defects. The treatment pattern and prognosis show significant differences between these three types.

This study reports a case of primary frontoethmoidal encephalocele diagnosed at 24 weeks of gestation.

\section{CASE REPORT}

An ultrasonographic examination at 23 weeks of pregnancy of a 23-year-old patient revealed a mass in the glabellar area on the midline of the face (Fig. I). This was her second pregnancy, and she already had one living child. 


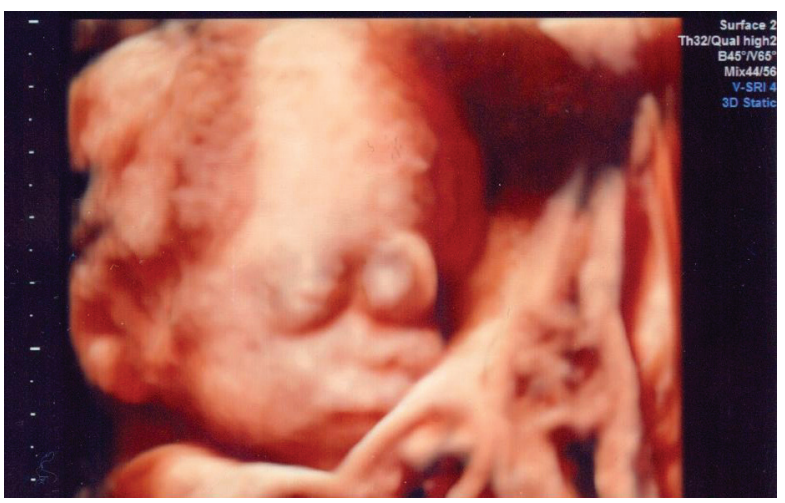

Figure 1. Four-dimension ultrasound image of the lesion.

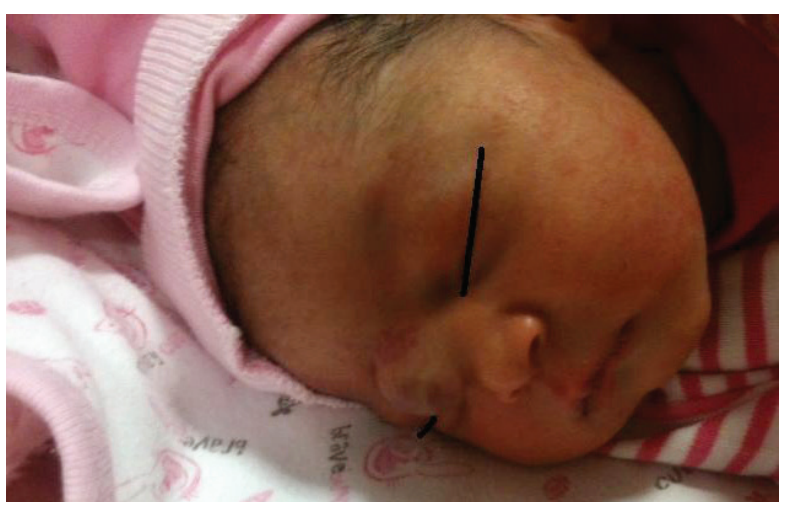

Figure 2. Image of the newborn.

The patient's double and triple screening tests were not available. No detailed anomalies were found in the detailed ultrasound. The amniotic fluid was normal. The mother's detailed history revealed that she had a single kidney and that she did not use any medication, including folic acid, during her pregnancy. No family history or any congenital anomaly history was found in the family.

The patient was born with a cesarean section at the $40^{\text {th }}$ week with a preliminary diagnosis of breech presentation. A $34 \mathrm{I0}-\mathrm{g}, 5 \mathrm{I}-\mathrm{cm}$ baby girl was delivered with an Apgar score of 8/9 (Fig. 2).

The craniofacial examination revealed no hypertelorism, but a skin-covered facial or nasal mass $(1.5 \mathrm{~cm}$ in size) was observed in the glabellar region.

All examinations, including ultrasonographic and ophthalmologic examinations, were normal. Computed tomographic evaluation revealed a frontoethmoidal encephalocele with a herniated sac $\left(13 \times 15 \times 15 \mathrm{~mm}^{3}\right.$ in size) comprising neural tissue (Fig. 3).

Written informed consent was obtained from the parent of the patient who participated in this study.

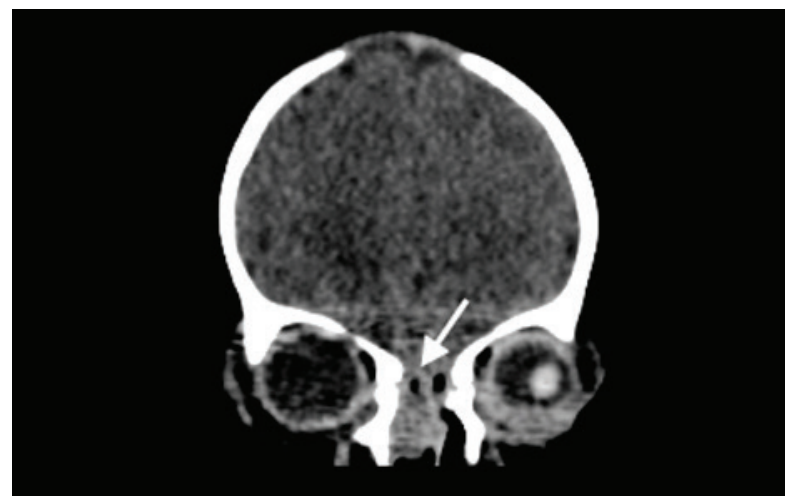

Figure 3. Postnatal appearance of the lesion in computerized tomography.

\section{DISCUSSION}

Cranium bifidum or cranioschisis is used to describe defects resulting from the insufficient union of the cranial bones. These defects are most often observed in the occipital region. Encephalocele is a protrusion of brain tissue and membranes in the form of a sac, and is almost always covered with skin texture.

While $80 \%$ of all encephaloceles in white populations of North America and Europe are occipital, anterior encephaloceles is more common in Southeast Asian countries such as Burma, Thailand, Malaysia, Indonesia, in some parts of Russia, and Central Africa. ${ }^{[4,5]}$

The frontoethmoidal type, which is the most common form, is observed in Thailand in every 5000 6000 births. Despite the high incidence in specific regions, very little is known about the etiology and pathogenesis of this disease, and often environmental factors are blamed as potential causes. ${ }^{[6,7]}$ Until now, only aflatoxin has been shown to be the teratogenic drug that may be responsible for these anomalies. ${ }^{[8]}$ Suwanwela et al., in a pair of identical twins, reported that only one of the twins had encephalocele, suggesting that environmental factors, rather than genetic factors, may be involved in the etiology. Many studies found that the incidence of anterior encephalocele was more frequent in rural areas where malnutrition and poor living conditions were present. ${ }^{[0]}$ The present case study was from a rural area, and no factors other than folic acid deficiency were detected in the etiology.

Isolated encephaloceles are usually sporadic. Encephaloceles accompanied by anomalies may be part of specific genetic syndromes. In a study, the incidence of at least one major structural defect was found to 
be $20 \%$ in living infants with encephalopathy. ${ }^{[10]}$ The present case study revealed an isolated encephalocele without any structural defect.

The mechanism of primary or innate encephalopathies is unclear but is thought to be caused by the defective closure of the anterior neural tube. Severe lesions are known to occur in the first 26 days after conception, whereas relatively simple lesions were caused by problems in later days. ${ }^{[1]}$

If the diagnosis is made in the prenatal period, consultation for antenatal brain surgery should be sought. Cesarean delivery may be preferred depending on the size of the lesion to prevent birth trauma and distosia. ${ }^{[12]} A$ vaginal delivery in the presence of small lesions is safe.

Anterior encephaloceles may be asymptomatic or may be followed by skin-covered facial or nasal mass accompanied by hypertelorism, telecanthus, orbital dystrophy, and unilateral micro- or anophthalmia. In addition, nasal congestion and cerebrospinal fluid (CSF) can also be symptomatic due to rhinosinus or recurrent meningitis. Encephaloceles may include normal brain tissue and fibrous atrophic gliotic neural tissue that have no function. Most of the herniated tissue in the nasofrontal encephalus contains nonfunctional gliotic neural tissue. ${ }^{[13,14]}$ In the present case study, the sac was small and not accompanied by defects such as hypertelorism or CSF leakage.

The preferred surgery time varies according to the symptom of the lesion. An emergency surgery is needed if the lesion leads to difficulty in breathing, if pressure is exerted on the eyes, or if CSF leakage from the lesion is observed; otherwise, the surgery can be delayed until the end of the neonatal period in asymptomatic cases. Arsim et al. recommended that the surgery should be performed after the body weight reaches $5-6 \mathrm{~kg}$ to minimize the loss of blood and hypothermia. ${ }^{[15]}$

The reason for not postponing the repair of the lesion to the later periods is to prevent the damage of the growing encephalocele over time to the craniofacial structure. Surgery is usually successful in encephalocele without causing major complications or mortality. Prognosis is usually good in isolated lesions and is often associated with normal intelligence quotient and motor development. ${ }^{[16]}$

In conclusion, anterior encephaloceles are rare lesions that can be diagnosed by ultrasonography in the antenatal period. All masses at the nasal region must be accepted as an encephalocele until proven otherwise. Epidermoid or dermoid cysts, vascular malformations, hemangiomas, gliomas, and congenital nasopharyngeal masses should be kept in mind in the differential diagnosis. Three-dimensional computerized tomography and magnetic resonance imaging are used to evaluate encephalosplasia.

Conflict of interest

None declared.

\section{REFERENCES}

1. Albert L Jr, DeMattia JA. Cocaine-induced encephalocele: case report and literature review. Neurosurgery 2011;68:263-6.

2. Antonelli V, Cremonini AM, Campobassi A, Pascarella R, Zofrea G, Servadei F. Traumatic encephalocele related to orbital roof fractures: report of six cases and literature review. Surg Neurol 2002;57:117-25.

3. Di Rocco F, Couloigner V, Dastoli P, Sainte-Rose C, Zerah M, Roger G. Treatment of anterior skull base defects by a transnasal endoscopic approach in children. J Neurosurg Pediatr 2010;6:459-63.

4. Rojvachiranonda N, David DJ, Moore MH, Cole J. Frontoethmoidal encephalomeningocele: new morphological findings and a new classification. J Craniofac Surg 2003;14:847-58.

5. Simpson DA, David DJ, White J. Cephaloceles: treatment, outcome, and antenatal diagnosis. Neurosurgery 1984;15:14-21.

6. Suwanwela C, Sukabote C, Suwanwela N. Frontoethmoidal encephalomeningocele. Surgery 1971;69:617-25.

7. Smit CS, Zeeman BJ, Smith RM, de V Cluver PF. Frontoethmoidal meningoencephaloceles: a review of 14 consecutive patients. J Craniofac Surg 1993;4:210-4.

8. Aung Thu, Hta Kyu. Epidemiology of frontoethmoidal encephalomeningocoele in Burma. J Epidemiol Community Health 1984;38:89-98.

9. Agthong S, Wiwanitkit V. Encephalomeningocele cases over 10 years in Thailand: a case series. BMC Neurol 2002;2:1-3.

10. Siffel C, Wong LY, Olney RS, Correa A. Survival of infants diagnosed with encephalocele in Atlanta, 1979-98. Paediatr Perinat Epidemiol 2003;17:40-8.

11. Czeizel AE, Dudás I. Prevention of the first occurrence of neuraltube defects by periconceptional vitamin supplementation. N Engl J Med 1992;327:1832-5.

12. Woodward KS. Diagnostic imaging obstetri. 2. Baskı. Çeviri Editörü: Özyüncü Ö. Güneş Tip Kitabevleri Ankara 2014:44-5.

13. Richards CG. Frontoethmoidal meningoencephalocele: a common and severe congenital abnormality in South East Asia. Arch Dis Child 1992;67:717-9.

14. David DJ. Cephaloceles: classification, pathology, and management-a review. J Craniofac Surg 1993;4:192-202.

15. Morina A, Kelmendi F, Morina Q, Dragusha S, Ahmeti F, Morina D. Treatment of anterior encephaloceles over 24 years in Kosova. Med Arh 2011;65:122-4.

16. Jimenez DF, Barone CM. Encephaloceles, meningoceles, and dermal sinuses. In: Albright AL, Pollack IF, Adelson PD, editors. Principles and Practice of Pediatric Neurosurgery. New York: Thieme; 1999. p. 189. 


\section{Prenatal Tanı Alan Primer Fronto-Etmoidal Ensefalosel: Olgu Sunumu}

Bu yazıda, 24. gebelik haftasında tanı konulan bir primer fronto-etmoidal ensefalosel olgusu sunmayı amaçladık. Ensefalosel en sık izlenen üç nöral tüp defektinden biridir, diğerleri anensefali ve spina bifidadır. Bu olguda yapılan ultrasonografide yüz orta hatta glabella bölgesinde kitle tesbit edildi, eşlik eden anomaliye rastlanmadı. Doğum sonrası yapılan muayene ve radyolojik değerlendirmede olguya, fronto-etmoidal ensefalosel tanısı konuldu. Bu olgular antenatal dönemde ultrason ile tanı konulabilen nadir lezyonlardır. Aksi isbat edilinceye kadar nazal bölgede izlenen her kitle ensefalosel olarak kabul edilmelidir.

Anahtar Sözcükler: Fronto-etmoidal ensefalosel; prenatal tanı; ultrasonografi. 